\title{
Social work and social justice: The relationship between fitness to practise and criminal convictions for non-violent activism
}

\author{
Nathan J. Williams, Capital and Coast District Health Board
}

\begin{abstract}
INTRODUCTION: Social work as a profession is underpinned by ideas of social justice and human rights, and that social workers have an ethical obligation to uphold these ideas. Social workers have a history of engagement in non-violent social justice activism (NVSJA), and a proud record of achieving social change in Aotearoa New Zealand. However, having a criminal conviction for engaging in NVSJA can be a barrier to social work registration in Aotearoa New Zealand.

APPROACH: An exploration of current research around NVSJA and social work registration was conducted. Along with an examination of the Social Workers Registration Board's (SWRB's) Fit and Proper Person Policy Statement, with a consideration on the reporting of acts of NVSJA and social workers by the media.
\end{abstract}

CONCLUSION: Those who engage in NVSJA are often likely to gain criminal convictions. This creates a potential barrier for social workers who go beyond the rhetoric and fight for social justice, in a macro and practical sense, from gaining registration. This has become additionally important since the Social Workers Registration Legislation Act (2019) passed and with registration becoming mandatory two years after the Act gained royal assent. There is a need for a change to the Fit and Proper Person Policy Statement so that the SWRB is better able to support social workers who are standing for what social work is all about, or at least, what social work is stated to be all about.

KEYWORDS: social justice; activism; convictions; fit and proper

AOTEAROA NEW ZEALAND SOCIAL WORK 31(2), 64-68.

CORRESPONDENCE TO: Nathan J. Williams nathan.williams@ccdhb. org.nz
Hayes, \& Smith, 2017). However, there is a disjunction between the Social Workers Registration Board's (SWRB) Fit and Proper Person Policy Statement and this idea. As it is not uncommon for social workers to engage in acts of NVSJA (Schrader, 2010). It, also, is not uncommon for those involved to be at risk of getting arrested for such acts, with Māori at higher levels of risk of gaining a conviction after arrest (Duarte, 2017; Eketone, 2015 Keane, 2012; Schrader, 2010). This currently could lead to a barrier in registration and employment as a social worker in Aotearoa New Zealand (Dennett \& Pratt, 2016; SWRB, 2018). 


\section{The current fit and proper person policy statement}

In Aotearoa New Zealand, the Social Workers Registration Legislation Act 2019 states the SWRB is required to consider any criminal convictions to help determine whether an applicant meets the criteria to be deemed a fit and proper person to practise social work. This is done on a case-by-case basis, where the board will review the nature of the criminal offence. As a part of this consideration, the circumstances of the offence, when and where the offence occurred, any rehabilitation undertaken by the applicant, the conduct of the applicant since the offence, along with a range of other factors are explored (SWRB, 2018). There is, however, no mention of criminal convictions for NVSJA in the SWRB's Fit and Proper Person Policy Statement.

\section{What does being fit and proper mean?}

The Social Workers Registration Legislation Act 2019 lays out three criteria that can lead to a social worker being deemed an unfit and improper person to practise social work in Aotearoa New Zealand. The first of these criteria is if the applicant has a conviction for an offence punishable by imprisonment of at least three months. The other two conditions concerning fit and proper status are whether the board is satisfied that the applicant is unable to adequately perform the actions required to be a social worker, or if there are reasonable grounds for the board to consider the applicant not to be of good character or reputation (Social Workers Registration Legislation Act, 2019). However, does being fit and proper go beyond this? Staniforth and Fouché (2006) argue that the most important factor to consider whether an applicant is a fit and proper person to practise social work is their potential liability to nga kiritaki (service users). Research conducted by Appleton, Rankine, and Hare (2014) reflects the views from social work academics and fieldwork educators. These views deemed fit and proper to include aspects such as the social worker's honesty, integrity, ability to know and work within their limits; ability to give and receive feedback; their capability to work interpersonally with $n g \bar{a}$ kiritaki; and their capacity to uphold the principles in the ANZASW's Code of Ethics (Appleton et al., 2014). Additionally, the research conducted by Appleton et al. (2014) showed that adherence to the principles of social justice and human rights; an ability to make ethical decisions; being culturally respectful and the ability to bring evidence into practice were all important in being considered fit and proper. In reality, the second and third criteria of the Social Workers Registration Legislation Act 2019 around an applicant being a fit and proper person to practise social work relate to the findings presented from Staniforth and Fouché (2006), and Appleton et al. (2014).

\section{The relationship between social work and social justice}

Ostrander et al. (2017) reported that part of being a social worker is to challenge unjust social systems, social injustices, and human rights violations. Social workers engaging in macro practice, which involves a push for social change, challenges to social inequalities and other social justice action (Austin, Anthony, Knee, \& Mathias, 2016), can create change for social workers in micro practice and for ngā kiritaki (McBeath, 2016; Reisch, 2016; Rothman \& Mizrahi, 2014). There is a strong belief across the social work profession that social workers have a responsibility to fight for social justice and social change, at both macro and micro levels (Clark, 2006; Duarte, 2017; Grodofsky \& Makaros, 2016; Hamilton \& Fauri, 2001; Morgaine, 2014; Payne, 2002; Rothman \& Mizrahi, 2014; Thompson, 2002). Standing up for social justice is more than rhetoric or an idealistic view of what social workers should aim to achieve. As Ostrander et al. (2017) reported, social workers have been on the front-lines fighting for social justice and social change historically in various circumstances through NVSJA. In fighting for social justice, a social worker's 
practice can, and often does, extend beyond their job description (Payne, 2000, as cited in Thompson, 2002). Engagement in NVSJA is often labelled radical social work in contemporary times, but historically, social workers have had a strong presence in social movements, in challenging social injustices in the political arena, and standing up for oppressed population groups (Noble, 2015; Reisch, 2016). Ostrander et al. (2017) acknowledge that participating in protests, marches, rallies, or joining civic organisations and political parties can be an effective method for social workers to meet the ethical obligations around social justice and human rights set out by the IFSW (2018).

\section{The Aotearoa New Zealand social justice activism context}

Participating in social activism is not foreign to New Zealanders. Our nation's history has been defined by acts of social activism, such as the Springbok Tour protests, 1984 Waitangi Day hīkoi, Vietnam War protests, anti-nuclear marches, and the homosexual reform marches (Keane, 2012; Schrader, 2010). More recently in Aotearoa New Zealand, we have had the foreshore and seabed hīkoi, the anti-mining rally, and the anti-TPPA protests (Fagan \& Bath, 2016; Gagné, 2008; Nippert, 2010). Many of these social protests, hīkoi, and marches have led to heavy police involvement (Keane, 2012). From this engagement in social justice activist events, there have been multiple arrests of New Zealanders (Baker, 2007; Schrader, 2010). As reported by Noble (2015) and Ostrander et al. (2017), social workers are often involved in these acts of NVSJA. Duarte (2017) refers to the social movements of the 1960s and 1970s and states that many social workers had heavy involvement in these social justice movements, fighting for social change. Having social workers heavily involved in these events, while many in attendance are arrested, indicates that a number of social workers are likely to have gained criminal convictions as a result of standing and fighting for social justice.

\section{International responses to regulating social workers with criminal convictions for NVSJA}

The policies of social work regulators and associations in the United States, Australia Canada, Northern Ireland, and England all had similar responses: that decisions on criminal convictions are made on a case-bycase basis relative to social work regulation (British Columbia College of Social Workers [BCCSW], 2018; Health and Care Professions Council [HCPC], 2012a, 2012b; New York State Education Department [NYSED], 2013; Northern Ireland Social Care Council [NISCC], 2017). In most cases, international social work regulators conduct a criminal record check on applicants (HCPC, 2012a; Social Workers Act, 2008). In policies available to the public from the international social work regulators community, there is no mention of criminal convictions in relation to NVSJA (BCCSW, 2018; HCPC, 2012b; NYSED, 2013; NISCC, 2017).

Looking at fitness to practice, CORU ${ }^{\mathrm{i}}$ (2010), the social work regulator for the Republic of Ireland reported that applicants must satisfy the registration board that they are a fit and proper person to practise social work by providing information on their character, health, knowledge, and skills. However, much like the other international regulators, CORU (2010) requires information on any criminal convictions of the applicant. The Northern Ireland Social Care Council (NISCC) (2015) outlines the values required by social workers to underpin their standards of conduct and practice. These include being respectful of individuals, working in a person-centred way, promoting the autonomy of nga kiritaki, (though of course the NISCC uses the term 'service users') acting in the best interests of $n g \bar{a}$ kiritaki, promoting equality and inclusiveness, and their ability to provide safe and effective care (NISCC, 2015). None of these international regulators had anything around NVSJA written into their publicly available policies on fitness to practise social work. 


\section{Criminal convictions and social workers}

The Ministry of Justice's Request for Criminal Conviction History form is something all social workers and social work students will be familiar with (Apaitia-Vague, Pitt, \& Younger, 2011). As social workers are regularly required to disclose their criminal convictions, the effects of their convictions can be felt across the entirety of their career. Dennett and Pratt (2016) reported on a community social worker who could not find employment as a social worker despite being qualified and applying for numerous positions, due to a conviction from 34 years earlier. Apaitia-Vague et al. (2011) published the difficulties of finding a position for students with criminal convictions in a generally risk-averse environment. When considering the effects of having a criminal conviction can have within the social work profession, we need to consider differences in conviction rates in Aotearoa New Zealand. In Aotearoa New Zealand, Māori are more likely to be arrested, convicted, denied diversion, or imprisoned than Pākehā for the same crimes (Department of Corrections, 2007; Eketone, 2015). As the SWRB's Fit and Proper Person Policy Statement considers applicants' criminal convictions, the fact that Māori are more likely to gain criminal convictions for the same crimes as Pākehā could lead to a potential barrier for Māori in becoming social workers registered with the SWRB.

\section{Conclusion}

There appears to be a disconnect between what research shows being fit and proper is, the ANZASW's Code of Ethics, and the SWRB's Fit and Proper Person Policy Statement (ANZASW, 2014; SWRB, 2018). While the current Fit and Proper Person Policy Statement does allow for case-by-case consideration, where the offence is explored in detail, it must be questioned whether this is enough. Does this accurately reflect the SWRB's view on the relationship between social work and social justice, and the ethical responsibility of social workers? With the longevity of the impacts of a criminal conviction on one's social work career, the likelihood of Aotearoa New Zealand social workers gaining convictions, and the cultural bias of our justice system, shouldn't the SWRB set an example for the social work profession around criminal convictions for NVSJA?

Do the professional bodies of social work in Aotearoa New Zealand, such as the ANZASW and SWRB, believe that social workers should stand up for social justice in a practical sense? If they do, why not let it be known in their policy statements or other publicly available documents? Acts of NVSJA have had such positive effects in Aotearoa New Zealand historically, and those involved should not be punished for taking a stand. Social workers are supposed to value macro practice, positive change, and social justice. If this is more than rhetoric, this should be reflected in the policy statements of the professional bodies for social work in Aotearoa New Zealand.

\section{Acknowledgement}

The author would like to thank and acknowledge Jan Duke and the Social Workers Registration Board for their guidance and supervision.

\section{Endnotes}

i The name CORU originates from an Irish word, 'cóir' meaning fair, just and proper. These are values that resonate deeply within the organisation, and reflect commitment to protecting the public by regulating health and social care professionals. CORU is not an acronym.

\section{References}

Aotearoa New Zealand Association of Social Workers. (2014). Code of ethics. Wellington, New Zealand: Author.

Apaitia-Vague, T., Pitt, L., \& Younger, D. (2011). "Fit and proper" and fieldwork: A dilemma for social work educators? Aotearoa New Zealand Social Work, 23(4), 55-64.

Appleton, C., Rankine, M., \& Hare, J. (2014). An appreciative inquiry into cultivating "fit and proper" social work students. In J. Duke, M. Henrickson, \& L. Beddoe (Eds.), Protecting the public - enhancing the profession: $E$ tiaki ana I te hapori - e manaaki ana I nga mahi: Edited proceedings from the Social Workers Registration Board conference 2013 (pp. 130-141). Wellington, New Zealand: Social Workers Registration Board.

Austin, M. J., Anthony, E. K., Knee, R. T., \& Mathias, J. (2016). Revisiting the relationship between micro and macro social work practice. Families in Society: The Journal of Contemporary Social Services, 97(4), 270-277. https://doi.org/10.1606/1044-3894.2016.97.33 
Baker, D. (2007). Policing, politics, and civil rights: Analysis of the policing of protest against the 1999 Chinese president's visit to New Zealand. Police Practice and Research, 8(3), 219-238. https://doi.org/10.1080/15614260701450708

British Columbia College of Social Workers. (2018). BCCSW "good character" policy. Vancouver, BC, Canada: Author.

Clark, C. (2006). Moral character in social work. British Journal of Social Work, 36(1), 75-89. https://doi.org/10.1093/bjsw/bch364

CORU. (2010). Fit and proper. Retrieved from http://www.coru.ie/

Dennett, K., \& Pratt, C. (2016, February 23). 34-year-old convictions hinder job hunt. Stuff. Retrieved from https://www.stuff.co.nz/auckland/76989040/null

Department of Corrections. (2007). Over-representation of Māori in the criminal justice system: An exploratory report. Policy, Strategy, and Research Group, Department of Corrections, September 2007. Retrieved from https://www.corrections.govt.nz/_data/assets/ pdf_file/0004/672574/Over-representation-of-Maori-inthe-criminal-justice-system.pdf

Duarte, F. (2017). Reshaping political ideology in social work: A critical perspective. Aotearoa New Zealand Social Work, 29(2), 34-44.

Eketone, A. (2015). Will the oppressed ever be able to participate in the social work profession? Aotearoa New Zealand Social Work, 27(4), 1-4.

Fagan, J., \& Bath, B. (2016, February 4). TPPA protests shut down Auckland intersections to "send a message." Stuff. Retrieved from https://www.stuff.co.nz/ auckland/76567783/TPPA-protests-shut-down-Aucklandintersections-to-send-a-message

Gagné, N. (2008). On the ethnicization of New Zealand politics: The foreshore and seabed controversy in context. The Asia Pacific Journal of Anthropology, 9(2), 123-140. https://doi.org/10.1080/14442210802023657

Grodofsky, M. M., \& Makaros, A. (2016). Social work and social protest: An under-researched field. Journal of Policy Practice, 15(4), 333-348. http://dx.doi.org/10.108 $0 / 15588742.2015 .1125328$

Hamilton, D., \& Fauri, D. (2001). Social workers' political participation: Strengthening the political confidence of social work students. Journal of Social Work Education, 37(2), 321-332. https://doi.org/10.1080/10437797.2001.10779057

Health and Care Professions Council. (2012a). Guidance on health and character: How we consider information that applicants or registrants declare. London, United Kingdom: Author.

Health and Care Professions Council. (2012b). Practice note: Conviction and caution allegations. London, United Kingdom: Author.

International Federation of Social Workers. (2018). Statement of ethical principles. Retrieved from https://www.ifsw.org/ statement-of-ethical-principles/

Keane, B. (2012). Ngā rōpū tautohetohe: Māori protest movements. Retrieved from http://www.TeAra.govt.nz/ en/nga-ropu-tautohetohe-maori-protest-movements

McBeath, B. (2016). Re-envisioning macro social work practice. Families in Society: The Journal of Contemporary Social Services, 97(1), 5-14. https://doi.org/10.1606/1044-3894.2016.97.9
Morgaine, K. (2014). Conceptualizing social justice in social work: Are social workers "too bogged down in the trees"? Journal of Social Justice, 4, 1-18.

New York State Education Department. (2013). Rules of the board of regents: Part 28, proceedings to determine good moral character and to evaluate prior disciplinary history for authorization to practice the licensed professions. Retrieved from http://www.op.nysed.gov/ title8/part28.htm\#subpart28-2

Nippert, M. (2010, May 2). Protesters halt city. New Zealand Herald. Retrieved from https://www.pressreader.com/new-zealand/herald-onsunday/20100502/281479272625600

Noble, C. (2015). Social protest movements and social work practice. In J. D. Wright (Ed), International encyclopedia of the social and behavioral sciences (2nd ed., pp 518-524). Melbourne, VIC, Australia: Elsevier.

Northern Ireland Social Care Council. (2015). Standards of conduct and practice for social workers. Retrieved from https://niscc.info/storage/resources/ web_optimised_91740_niscc_standards_of_conduct and_practice_bluepurple.pdf

Northern Ireland Social Care Council. (2017). Indicative sanctions and use of interim orders: Guidance for fitness to practise committees. Retrieved from https://niscc. info/storage/resources/20170602_indicative-sanctionsguidance_v12_hmcv.pdf

Ostrander, J. A., Lane, S., McClendon, J., Hayes, C., \& Smith, T.R. (2017). Collective power to create a political change: Increasing the political efficacy and engagement of social workers. Journal of Policy Practice, 16(3), 261-275. https://doi.org/10.1080/ 15588742.2016.1266296

Payne, M. (2002). Balancing the equation. Professional Social Work, January, 12-13.

Reisch, M. (2016). Why macro practice matters. Journal of Social Work Education, 52(3), 258-268. https://doi.org/10.1080/10437797.2016.1174652

Rothman, J., \& Mizrahi, T. (2014). Balancing micro and macro practice: A challenge for social work. Social Work, 59(1), 91-93. https://doi.org/10.1093/sw/swt067

Schrader, B. (2010). Parades and protest marches. Retrieved from https://teara.govt.nz/en/parades-and-protestmarches

Social Workers Act (2008). British Columbia, Canada Retrieved from http://www.bclaws.ca/civix/document/id/ consol31/consol31/00_08031_01

Social Workers Registration Legislation Act (2019). New Zealand. Retrieved from http://www.legislation.govt.nz/ act/public/2019/0003/22.0/DLM7396614.html

Social Workers Registration Board. (2018). Fit and proper person: Policy statement. Retrieved from http://swrb.govt.nz/about-us/policies/

Staniforth, B., \& Fouché, C. (2006). An Aotearoa primer on "fit and proper": School version. Social Work Review, Summer 2006, 11-19.

Thompson, N. (2002). Social movements, social justice, and social work. British Journal of Social Work, 32, 711-722. https://doi.org/10.1093/bjsw/32.6.711 